\title{
Chapter 7. Statewide White-Skinned Potato Variety Trials, 20061
}

\section{C.M. Hutchinson and Doug Gergela ${ }^{2}$}

General Comments: A goal of the statewide potato variety trial is to identify advanced potato selections for Florida production. Established varieties were included to provide a baseline for comparison.

\section{Planting Information}

Florida Statewide White Potato Trial (Tables 17 and 18).

Planting Dates

Harvest Dates

Season Length

Fertilizer Program

Irrigation Program
PSREU - Hastings Farm (PSREU), One Site in Bunnell, One Site in Hastings, and Two Sites in Immokalee (1 and 2) PSREU (2/1/06), Bunnell (1/25/06), Hastings (1/26/06), and Immokalee 1and 2 (11/30/05) PSREU (5/18/06), Bunnell (5/9/06), Hastings (5/8/06), and Immokalee 1 and 2 (3/28/06) PSREU (86), Bunnell (104), Hastings (102), Immokalee 1(101), and Immokalee 2 (101)

Grower standard practices for all sites except PSREU, which is similar to the White Variety Trial (Chapter 3).

seepage

Experimental Design

Number of Sites 5

\begin{tabular}{|l|l} 
Number of Selections & 8
\end{tabular}

\begin{tabular}{|l|l} 
Within Row Spacing & 8 in $(20.3 \mathrm{~cm})$
\end{tabular}

Between Row Spacing $38-42$ in $(96.5-106.6 \mathrm{~cm})$

Replications 4 at each site

Plot Size $16 \mathrm{ft}(4.9 \mathrm{~m})$ single row

Production Statistics- Based over all sites

Highest Total Yield Carrera (456 cwt/acre or $51.1 \mathrm{MT} / \mathrm{ha})$

Highest Marketable Yield

LaChipper (339 cwt/acre or $38.0 \mathrm{MT} / \mathrm{ha}$ )

1. This document is HS1091, one of a series of the Horticultural Sciences Department, Florida Cooperative Extension Service, Institute of Food and Agricultural Sciences, University of Florida. Original publication date March 21, 2007. Visit the EDIS Web Site at http://edis.ifas.ufl.edu.

2. Chad M. Hutchinson, Associate professor, Doug Gergela, Sr. Bilogical Scientist, Horticultural Sciences Department, Cooperative Extension Service, Institute of Food and Agricultural Sciences, University of Florida, Gainesville, 32611.

The use of trade names in this publication is solely for the purpose of providing specific information. UF/IFAS does not guarantee or warranty the products named, and references to them in this publication does not signify our approval to the exclusion of other products of suitable composition. All chemicals should be used in accordance with directions on the manufacturer's label. Use pesticides safely. Read and follow directions on the manufacturer's label.

The Institute of Food and Agricultural Sciences (IFAS) is an Equal Opportunity Institution authorized to provide research, educational information and other services only to individuals and institutions that function with non-discrimination with respect to race, creed, color, religion, age, disability, sex, sexual orientation, marital status, national origin, political opinions or affiliations. U.S. Department of Agriculture, Cooperative Extension Service, University of Florida, IFAS, Florida A. \& M. University Cooperative Extension Program, and Boards of County Commissioners Cooperating. Larry Arrington, Dean 


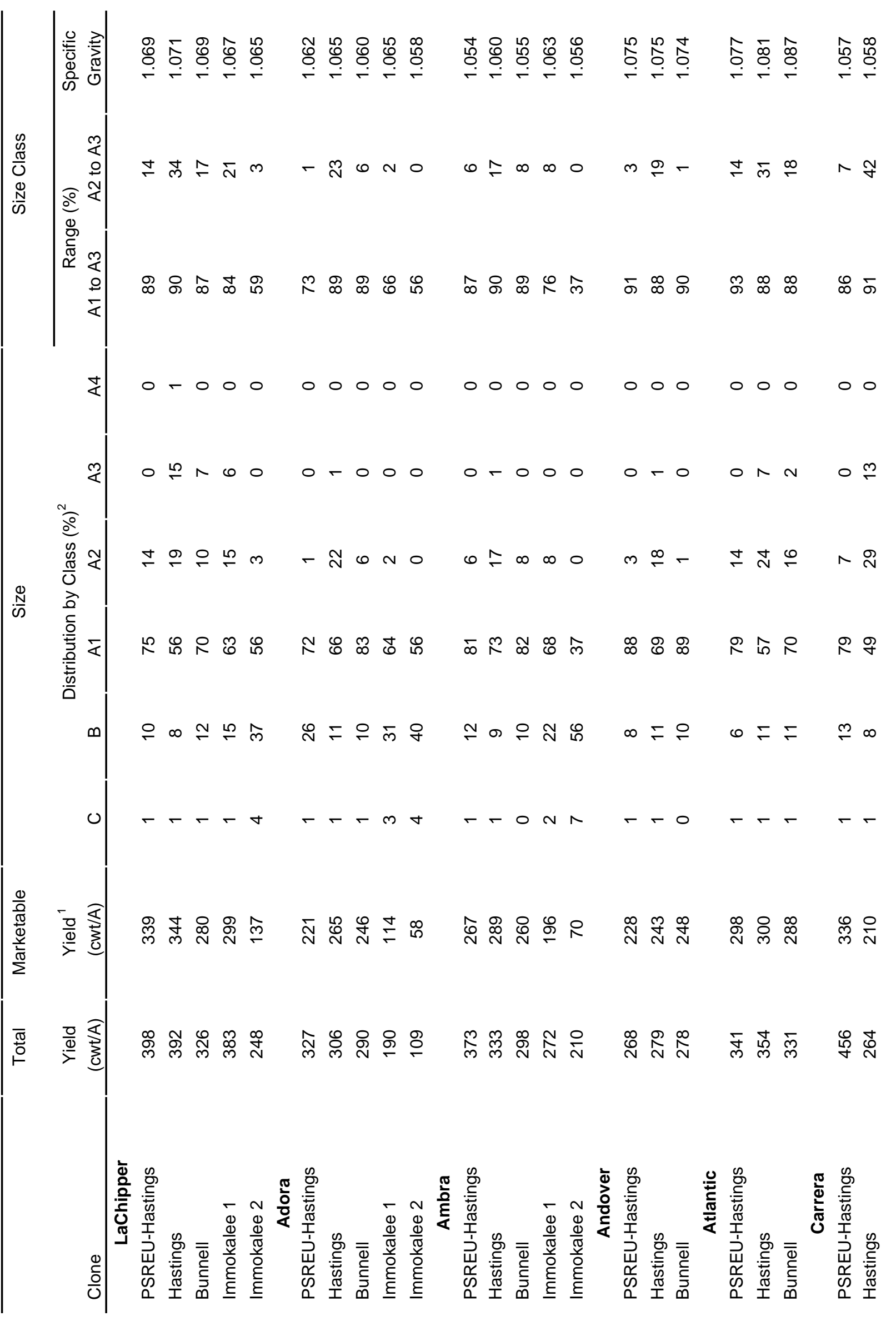




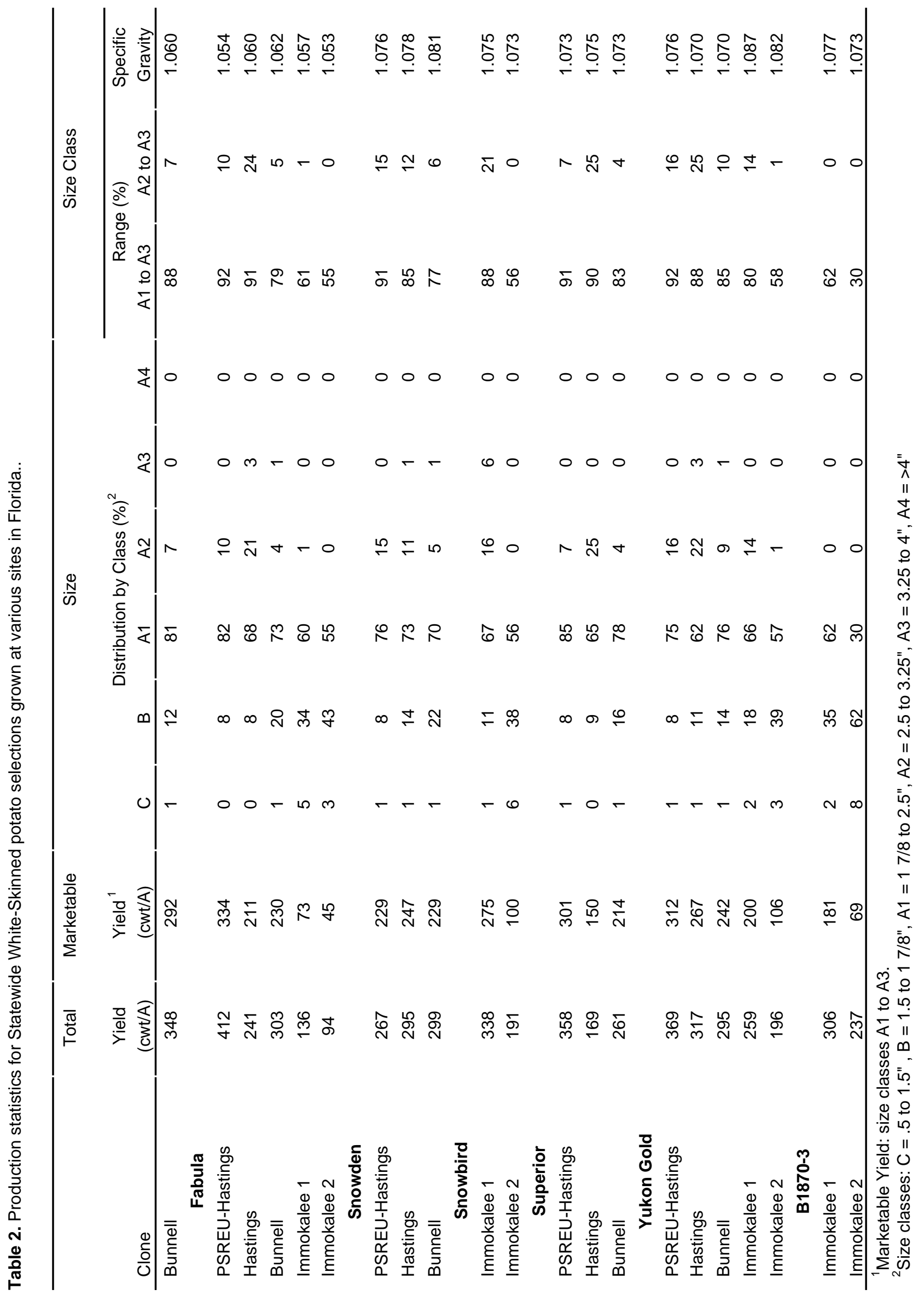




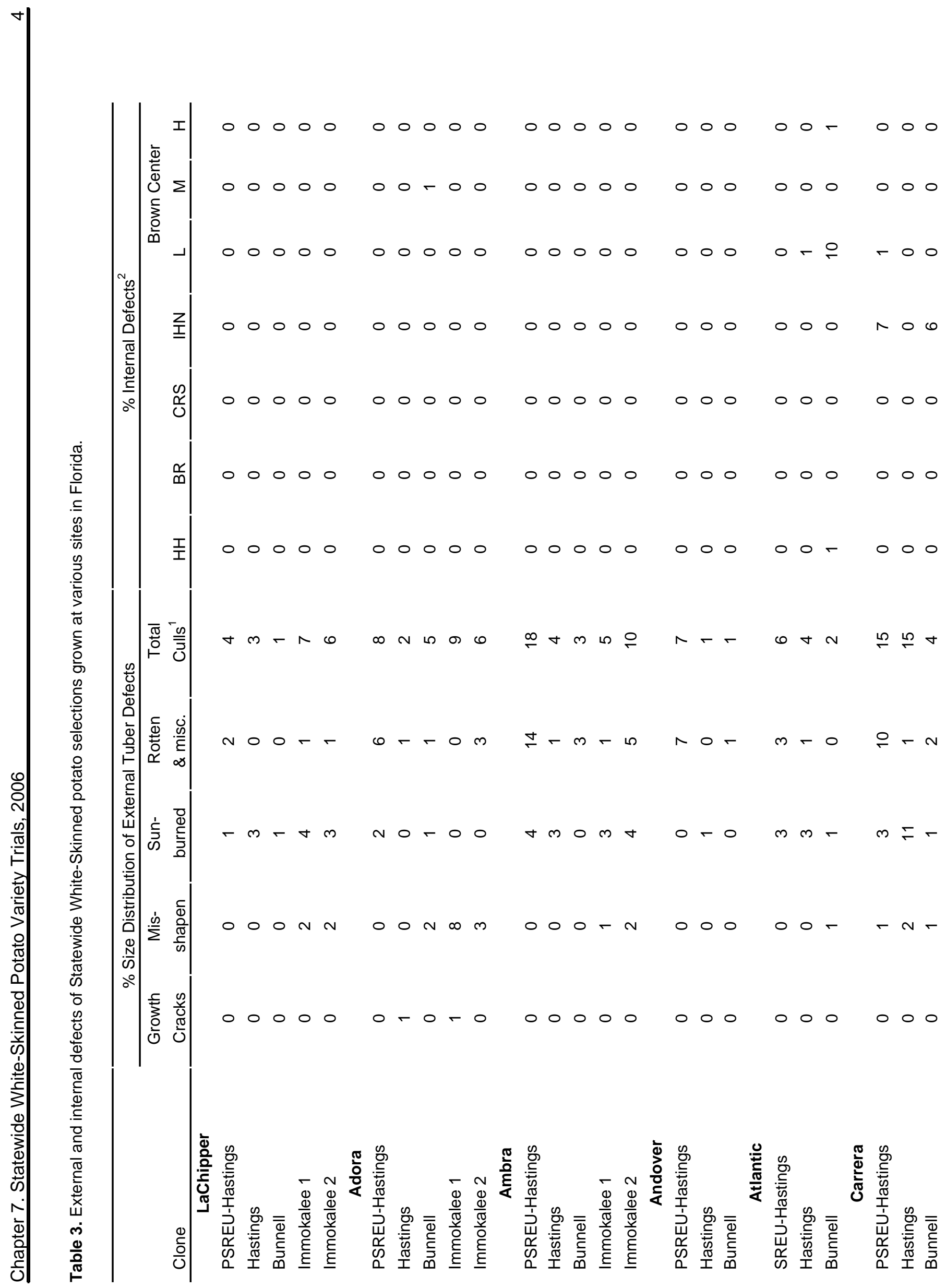




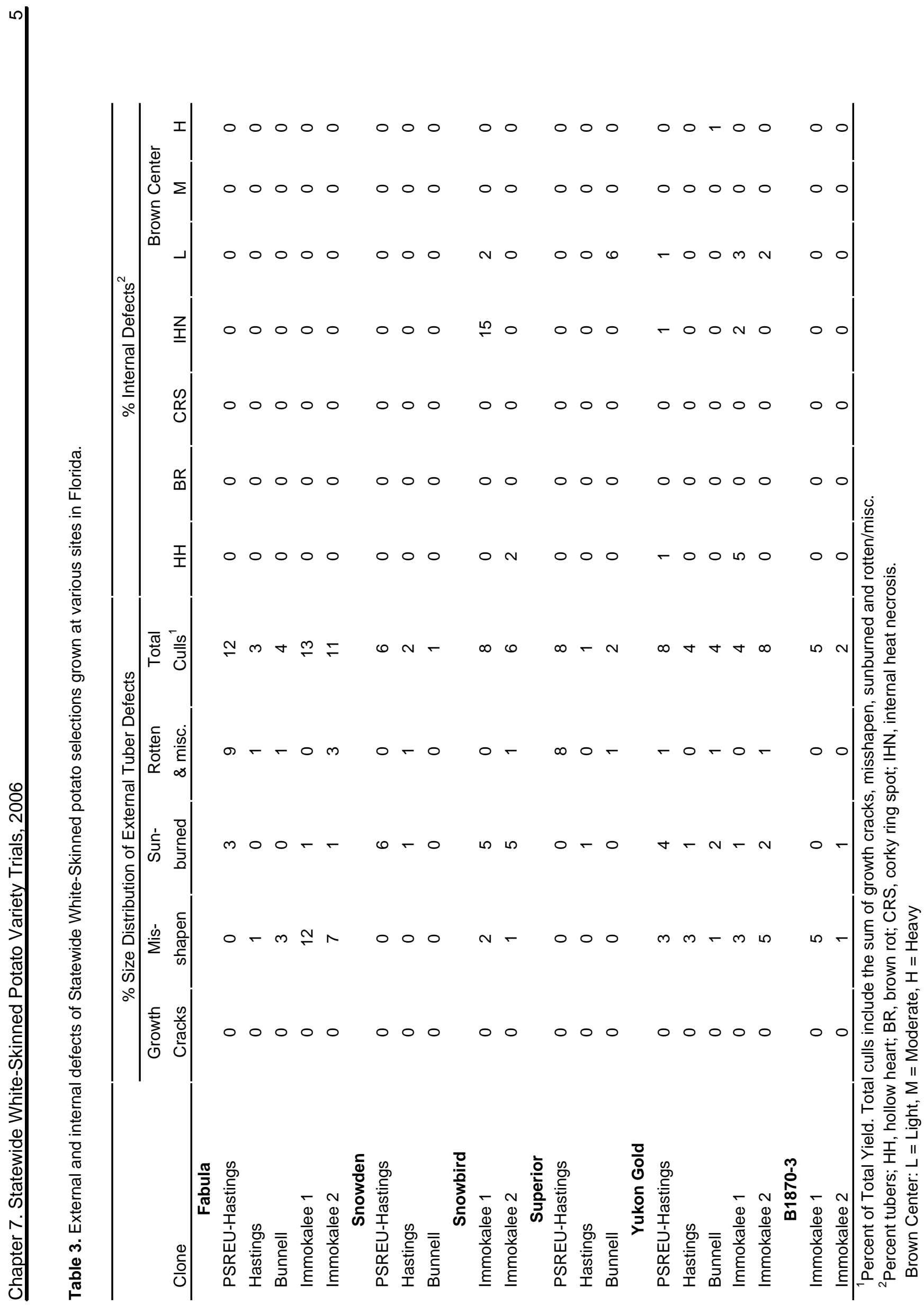

